\title{
Konsep Diri pada Masa Remaja Akhir dalam Kematangan
}

\section{Karir Siswa}

\author{
Fitri Nur Rohmah Dewi \\ Universitas Islam Negeri Sunan Kalijaga, Yogyakarta, Indonesia \\ fitrinurrohmahdewo09@gmail.com
}

\begin{abstract}
Abstrak
Tujuan penelitian ini adalah untuk menggali dan memahami secara teoritik dan filosofis mengenai konsep diri pada masa remaja akhir dalam kematangan karir. Penelitian ini menggunakan metode penelitian library research (penelitian kepustakaan). Adapun hasil penelitian ini adalah: Kamatangan karir dapat diatasi jika seseorang pada masa remaja akhir dapat memaksimalkan konsep diri pada dirinya termasuk faktor internal dan eksternal didalamnya. Faktor internal yang dapat mempengaruhi konsep diri yakni: 1) diri identitas (identity self), 2) diri pelaku (behavioral self), dan 3) diri penerimaan atau penilaan (judging self). Sedangkan faktor eksternal yang dapat mempengaruhi konsep diri yakni: 1) diri fisik (physical self), 2) diri etika-normal (moral-ethical self), 3) diri pribadi (personal self), 4) diri keluarga (family self), dan 5) diri sosial (social self). Konsep diri perlu ada pada masa remaja akhir karena dengan keyakinan bahwa semua pencapaian ditentukan oleh usaha, keterampilan dan kemampuan, maka anak pada masa remaja akhir akan berusaha meningkatkan kemampuan dan keterampilan yang menjadi persyaratan karir.
\end{abstract}

Kata kunci: Konsep Diri, Kematangan Akhir, dan Masa Remaja Akhir.

\section{Abstrack}

Self-Concept in Late Adolescence in Students' Career Maturity. The purpose of this study is to explore and understand theoretically and philosophically about self-concept in late adolescence in career maturity. This study uses library research research methods (library research). The results of this study are: Career maturity can be overcome if a person in late adolescence can maximize his selfconcept, including internal and external factors in it. Internal factors that can influence self-concept are: 1) self-identity, 2) behavioral self, and 3) selfacceptance or judgment (judging self). While external factors that can influence self-concept are: 1) physical self, 2) ethical-normal self (moral-ethical self), 3) 
personal self (personal self), 4) family self (family self), and 5) social self. Selfconcept needs to exist in late adolescence because with the belief that all achievements are determined by effort, skills and abilities, children in late adolescence will try to improve the abilities and skills that are career requirements.

Keywords: Self-Concept, Late Maturity, and Late Adolescence.

\section{A. Pendahuluan}

Seseorang dilahirkan ke dunia ini belum memiliki konsep diri, tidak memiliki pengetahuan tentang diri, dan tidak memiliki pengharapan apa pun terhadap diri kita sendiri. Konsep diri terbentuk melalui proses belajar yang berlangsung sejak masa pertumbuhan hingga dewasa. Didalam perkembangan anak banyak dibicarakan bahwa dasar kepribadian seseorang terbentuk pada masa anak anak. Proses perkembangan yang terjadi dalam diri seseorang anak ditambah dengan apa yang dialami dan diterima selama masa anak-anaknya secara sedikit demi sedikit memungkinkan ia tumbuh dan berkembang menjadi manusia dewasa (Suwargarini, 2018). William H. Fitts (1971) mengemukakan bahwa konsep diri merupakan aspek penting dalam diri seseorang, karena konsep diri seseorang merupakan kerangka acuan (frame of reference) dalam berinteraksi dengan lingkungan. Ia menjelaskan konsep diri secara fenomenologis, dan mengatakan bahwa ketika individu mempersepsikan dirinya, bereaksi terhadap dirinya, memberikan arti dan penilaian serta memberikan abstraksi tentang dirinya, berarti ia menunjukkan suatu kesadaran diri (self awareness) dan kemampuan untuk keluar dari dirinya sendiri untuk melihat dirinya seperti yang ia lakukan terhadap dunia di luar dirinya. Diri secara keseluruhan (total self) seperti yang dialami individu disebut juga diri fenomenal. Diri fenomena Ini adalah diri yang diamati, dialami, dan dinilai oleh individu sendiri, yaitu diri yang ia sadari. Keseluruhan kesadaran atau persepsi ini merupakan gambaran tentang diri atau konsep diri individu (Suwargarini, 2018).

Proses pembentukan konsep diri pada masa remaja menuju masa dewasa merupakan masa menuju dunia pekerjaan atau karir yang sebenarnya. Pekerjaan 
merupakan salah satu aspek yang penting dalam kehidupan manusiadewasa di mana pun dan kapan pun mereka berada. Pekerjaan seseorang memiliki konsekuensi yang besar bagi diri dan merupakan inti dari dasar dan tujuan hidup seseorang, oleh karena itu, menentukan pilihan karir menjadi titik penting dalam perjalanan hidup manusia. Kita dapat melihat konsep diri seseorang dari sikap mereka. Konsep diri yang jelek akan mengakibatkan rasa tidak percaya diri, tidak berani mencoba hal hal baru, tidak berani mencoba hal yang menantang, takut gagal, takut sukses, merasa diri bodoh, rendah diri, merasa diri tidak berharga, merasa tidak layak sukses, pesimis dan masih banyak perilaku inferior lainnya (Suwargarini, 2018). Permasalahan karir yang terjadi pada masa remaja akhir biasanya berkaitan dengan pemilihan jenis pendidikan, yang mengarah pada pemilihan jenis pekerjaan di masa depan, perencanaan karir masa depan, pengambilan keputusan tentang karir masa depan, dan informasi dengan kelompok kerja yang ada dengan persyaratan yang harus dimiliki. Permasalahan ini penting untuk diperhatikan karena banyak anak pada masa remaja akhir yang kebingungan dalam menentukan arah karir di masa depan, akibatnya berpengaruh pada pada pencapaian kematangan karir remaja (Leksana, 2013). Permasalahan karir pada siswa dapat ditangani dengan layanan bimbingan dan konseling, karena Bimbingan dan konseling bertujuan untuk membantu peserta didik agar dapat mencapai tujuan-tujuan perkembangannya yang meliputi aspek pribadi-sosial belajar (akademik) dan karir (Bastomi, 2019)

Pada masa remaja akhir yang berkisar usia 17-22 tahun merupakan tahapan remaja yang mulai berfikir tentang bidang pekerjaan apa yang diinginkan dan sanggup dijalani untuk kehidupan di masa depannya. Kebimbangan dalam menentukan karir menunjukkan bahwa individu tersebut tidak memiliki kematangan dalam karir di masa depan. Winkel mengungkapkan faktor internal yang dapat mempengaruhi kematangan karir adalah nilai-nilai kehidupan (values), taraf inteligensi, bakat khusus, minat, kepribadian, dan pengetahuan(Pratama, 2014). Sedangkan faktor eksternal yang mempengaruhi kematangan karir siswa adalah lingkungan sosial budaya tempat siswa 
dibesarkan, status sosial ekonomi keluarga, pengaruh keluarga, pendidikan sekolah, pergaulan dengan teman sebaya dan tuntutan yang melekat pada pekerjaan (Pratama, 2014). Berdasarkan faktor internal yang dikemukakan oleh Winkel tersebut, konsep diri penting dimiliki bagi remaja akhir karena dengan keyakinan bahwa semua pencapaian ditentukan oleh usaha, keterampilan dan kemampuan, maka anak pada masa remaja akhir akan berusaha meningkatkan kemampuan dan keterampilan yang menjadi persyaratan karir. Kematanagan karir juga sangat penting dimiliki oleh anak pada masa remaja akhir agar mereka dapat membuat pilihan karir yang tepat (Killing, 2015).

\section{B. Metode}

Metode yang digunakan dalam penulisan artikel ini adalah penelitian kepustakaan (library research), kepustakaan (library research) yaitu upaya menggunakan kajian pustaka dalam mendapatkan data dari dokumen kepustakaan seperti buku, kitab, majalah, jurnal dan dokumen lainnya (Zed, 2004: 27). Teknik kepustakaan meliputi metode dokumentasi, yakni dengan mengumpulkan dan menganalisis dokumen-dokumen, baik dokumen tertulis, gambar maupun dokumen lainnya (Sukmadinata, 2005: 246). Dalam penulisan artikel ini menggunakan metode analisi deskriptif analitik, yakni cara dan strategi dengan tujuan untuk mendeskripsikan suatu gambaran terhadap suatu objek penelitian yang dikaji melalui data yang telah terkumpul yang kemudian membuat kesimpulan yang berlaku umum (Sugiyono, 2016: 176).

\section{Pembahasan}

\section{Konsep Diri pada Anak}

Santrock dalam Yolanda Puspita Dewi dan Heru Mugiarso (2020) memandang bahwa konsep diri disebut juga martabat diri (self-worth) atau gambaran diri (self-image). Pada bagian ini, terkadang remaja tidak hanya memandang dirinya sebagai pribadi biasa saja namun pribadi yang lebih baik. mencoba-coba segala hal dan menganggap apa yang dilakukannya adalah yang terbaik. Padahal tidak semua remaja memiliki konsep diri yang positif. Menurut Brooks (1974) dalam Yolanda Puspita Dewi dan Heru Mugiarso (2020) 
mengemukakan bahwa konsep diri adalah pandangan dan penilaian kita tentang diri kita.

Konsep diri merupakan gambaran keseluruhan aspek kepribadian individu berdasarkan pada pandangan, persepsi, pikiran, perasaan, dan keyakinan individu terhadap dirinya sendiri. Gambaran ini sekaligus membentuk penghargaan dan penerimaan terhadap dirinya. Konsep diri bukan merupakan faktor bawaan dalam diri individu. Individu membentuk konsep diri dari pengalamannya dalam berhubungan dengan individu yang lain. Oleh karena itu, konsep diri memiliki peran yang penting dalam menentukan tingkah laku individu (Dewi \& Mugiarso, 2020).

Menurut Hurlock konsep diri merupakan gabungan dari keyakinan fisik, psikologis, sosial, emosional aspiratif, dan prestasi yang mereka capai. Konsep diri adalah apa yang dipikirkan dan dirasakan tentang dirinya sendiri. Ada dua konsep diri, yaitu konsep diri komponen kognitif dan konsepdiri komponen afektif. Komponen kognitif disebut self image dan komponen afektif disebut self esteem. Komponen kognitif adalah pengetahuan individu tentang dirinya mencakup pengetahuan "siapa saya” yang akan memberikan gambaran tentang diri saya. Gambaran ini disebut citra diri. Sementara itu, komponen afektif merupakan penilaian individu terhadap dirinya sendiri yang akan membentuk bagaimana penerimaan terhadap diri dan harga diri individu (Ghufron \& Risnawita, 2016: 78).

Konsep diri merupakan gambaran yang dimiliki seseorang tentang dirinya, yang dibentuk melalui pengalaman-pengalaman yang diperoleh dari interaksi dengan lingkungan. Konsep diri bukan merupakan faktor bawaan, melainkan berkembang dari pengalaman yang terus-menerus dan terdiferensiasi. Dasar dari konsep diri individu ditanamkan pada saat-saat dini kehidupan anak dan menjadi dasar yang mempengaruhi tingkah lakunya di kemudian hari. Menurut Campbell, satu faktor penting yang berpengaruh besar terhadap perubahan konsep diri adalah self concep clarity, yaitu sejauh mana konsep diri seseorang itu secara internal konsisten, stabil, dan dipegang dengan keyakinan (Rahman, 2014: 56). 
Fitts juga mengatakan bahwa konsep diri berpengaruh kuat terhadap tingkah laku seseorang. Dengan mengetahui konsep diri seseorang, kita akan lebih mudah meramalkan dan memahami tingkah laku orang tersebut. Pada umumnya tingkah laku individu berkaitan dengan gagasan-gagasan tentang dirinya sendiri. Jika seseorang mempersiapkan dirinya sebagai orang yang inferior dibandingkan dengan orang lain, walaupun hal ini belum tentu benar, biasanya tingkah laku yang ia tampilkan akan berhubungan dengan kekurangan yang bersih secara subjektif tersebut (Ghufron \& Risnawita, 2016: 79).

Pembentukan konsep diri tidak berkembang dengan sendirinya, tetapi terbentuk dengan adanya interaksi dengan individu yang lain khususnya dengan lingkungan sosial. Calhou dan Acocella, mengemukakan tentang sumber informasi yang penting dalam pembentukan konsep diri antara lain: (1) orangtua, dikarenakan orangtua adalah kontak sosial yang paling kuat dialami oleh individu; (2) teman sebaya, teman sebaya menempati peringkat kedua karena selain individu membutuhkan cinta dari orantua juga membutuhkan penerimaan dari teman sebaya dan apa yang diungkapkan pada diriny akan menjadi penilaian terhadap diri individu tersebut; (3) masyarakat, dalam masyarakat terdapat norma-norma yang akan membentuk konsep diri pada individu, misalnya pemberian perlakuan yang berbeda pada laki-laki dan perempuan akan membuat laki-laki dan perempuan berbeda dalam berprilaku (Ghufron \& Risnawita, 2016: 80).

Konsep diri seseorang dapat dipengaruhi oleh beberapa faktor antara lain sebagai berikut: (1) Pengalaman, terutama pengalaman interpersonal, yang memunculkan perasaan positif dan perasaan berharga, (2) Kompetensi dalam area yang dihargai oleh individu dan orang lain, (3) Aktualisasi diri, atau implementasi dan realisasi dari potensi pribadi dan sebenarnya (Agustiani, 2009: 160).

Menurut Fitts, konsep diri dibagi menjadi dua dimensi pokok, yaitu dimensi internal dan dimensi eksternal.Dimensi internal atau yang disebut juga kerangka acuan internal (internal frame of reference) adalah penilaian yang dilakukan 
individu yakni penilaian yang dilakukan individu terhadap dirinya sendiri berdasarkan dunia di dalam dirinya. Dimensi ini terdiri dari tiga bentuk:

\section{a. Diri identitas (identity self)}

Bagian diri ini merupakan aspek yang paling mendasar pada konsep diri dan mengacu pada pertanyaan, "Siapa saya?" dalam pertanyaan tersebut tercakup label-label dan simbol-simbol yang diberikan pada diri (self) oleh individu-individu yang bersangkutan untuk menggambarkan dirinya dan membangun identitasnya, misalnya "Saya Ita". Kemudian dengan bertambahnya usia dan interaksi dengan lingkungannya, pengetahuan individu tentang dirinya juga bertambah, sehingga ia dapat melengkapi keterangan tentang dirinya dengan hal-hal yang lebih kompleks, seperti "Saya pintar tetapi terlalu gemuk" dan sebagainya. Pengetahuan individu tentang dirinya juga bertambah, sehingga ia dapat melengkapi keterangan tentang dirinya dengan hal-hal yang lebih kompleks, seperti "Saya pintar tapi terlalu gemuk" dan sebagainya (Agustiani, 2009: 161).

\section{b. Diri pelaku (behavioral self)}

Diri pelaku merupakan persepsi individu tentang tingkah lakunya, yang berisikan segala kesadaran mengenai "apa yang dilakukan oleh diri”. Selain itu bagian ini berkaitan erat dengan diri identitas. Diri yang adekuat akan menunjukkan adanya keserasian antara diri identitas dengan diri pelakunya, sehingga ia dapat menggali dan menerima baik diri sebagai identitas maupun diri sebagai pelaku. Kaitan dari keduanya dapat dilihat pada diri sebagai penilai (Agustiani, 2009: 162).

c. Diri penerimaan/penilai (judging self)

Diri penilai memiliki fungsi diantaranya sebagai pengamat, penentu standar, dan evaluator.Kedudukannya adalah sebagai perantara (mediator) antara diri identitas dan diri pelaku. Manusia cenderung memberikan penilaian 
terhadap apa yang dipersepsikannya. Oleh karena itu, label-label yang dikenakan pada dirinya bukanlah semata-mata menggambarkan dirinya, tetapi juga sarat dengan nilai-nilai. Selanjutnya, penilaian ini lebih berperan dalam menentukan tindakan yang akan ditampilkannya.

Diri penilai menentukan kepuasan seseorang akan dirinya atau seberapa jauh seseorang menerima dirinya. Kepuasan diri yang rendah akan menimbulkan harga diri (self esteem) yang rendah pula dan akan mengembangkan ketidakpercayaan yang berdasar pada dirinya. Sebaliknya, bagi individu yang memiliki kepuasan diri yang tinggi, kesadaran dirinya lebih realistis, sehingga lebih memungkinkan individu yang bersangkutan untuk melupakan keadaan dirinya dan memfokuskan energi serta perhatiannya ke luar diri, dan pada akhirnya dapat berfungsi lebih konstruktif.

Sedangkan dimensi eksternal merupakan suatu hal yang luas, misalnya diri yang berkaitan dengan sekolah, organisasi, agama, dan sebagainya.Pada dimensi eksternal ini, individu menilai dirinya melalui hubungan dan aktivitas sosialnya, nilai-nilai yang dianutnya, serta hal-hal lain diluar dirinya. Namun, dimensi yang dikemukakan oleh Fitts adalah dimensi eksternal yang bersifat umum bagi semua orang dan dibedakan atas lima bentuk, yaitu:

a. Diri fisik (physical self): Diri fisik menyangkut persepsi seseorang terhadap keadaan dirinya secara fisik.Dalam hal ini terlihat persepsi seseorang mengenai kesehatan dirinya, penampilan dirinya (cantik, jelek, menarik, dan tidak menarik) dan keadaan tubuhnya (tinggi, pendek, gemuk, dan kurus) (Agustiani, 2009: 163).

b. Diri etika-moral (moral-ethical self): Bagian ini merupakan persepsi seseorang terhadap dirinya dilihat dari standar pertimbangan nilai moral dan etika. Hal ini menyangkut persepsi seseorang mengenai hubungan dengan Tuhan, kepuasan seseorang akan kehidupan keagamaan nya dan nilai-nilai moral yang dipegangnya, yang meliputi batasan baik dan buruk.

c. Diri pribadi (personal self): Diri pribadi merupakan perasaan atau persepsi seseorang tentang keadaan pribadinya. Hal ini tidak dipengaruhi oleh kondisi 
fisik atau hubungan dengan orang lain, tetapi dipengaruhi oleh sejauh mana individu merasa puas terhadap pribadinya atau sejauh mana ia merasa dirinya sebagai pribadi yang tepat.

d. Diri keluarga (family self): Diri keluarga menunjukkan perasaan dan harga diri seseorang dalam kedudukannya sebagai anggota keluarga.Bagian ini menunjukkan seberapa jauh seseorang merasa adekuat terhadap dirinya sebagai anggota keluarga, serta terhadap peran maupun fungsi yang dijalankannya sebagai anggota dari suatu keluarga.

e. Diri sosial (social self): Bagian ini merupakan penilaian individu terhadap interaksi dirinya dengan orang lain maupun lingkungan di sekitarnya (Agustiani, 2009).

Pembentukan penilaian individu terhadap bagian-bagian dirinya dalam dimensi eksternal ini dapat dipengaruhi oleh penilaian dan interaksinya dengan orang lain. Seseorang tidak dapat begitu saja menilai bahwa ia memiliki fisik yang baik tanpa adanya reaksi dari orang lain yang memperlihatkan bahwa memperlihatkan bahwa secara fisik ia memang menarik. Demikian pula seseorang tidak dapat mengatakan bahwa ia memiliki diri pribadi yang baik tanpa adanya tanggapan atau reaksi orang lain disekitarnya yang menunjukkan bahwa Ia memang memiliki pribadi yang baik (Agustiani, 2009: 163).

Seluruh bagian diri ini, baik internal maupun eksternal, saling berinteraksi dan membentuk suatu kesatuan yang utuh untuk menjelaskan hubungan antara dimensi internet dan dimensi eksternal, Fitts mengemukakan suatu analogi dengan mengumpamakan diri secara keseluruhan sebagai sebuah jeruk, yang dapat dipotong secara horizontal maupun vertikal. Potongan yang diperoleh dengan cara horizontal akan tampak berbeda dari yang dipotong secara vertikal, walaupun keduanya merupakan bagian dari suatu keseluruhan yang sama. Jika bagian-bagian internet dianggap sebagai lapisan-lapisan yang membentuk jeruk tersebut, maka diri identitas merupakan bagian yang paling dalam, diri tingkah laku merupakan kulit luar, dan diri menerima bagian yang kedua bagian lainnya (Agustiani, 2009: 164). 
Sedangkan bagian diri eksternal dapat diumpamakan sebagai bagian-bagian vertikal dari jeruk itu. Masing-masing merupakan bagian lain, dan semua bagian itu turut menemukan bentuk struktur jeruk tersebut secara keseluruhan. Bagianbagian internal dan eksternal tersebut saling berinteraksi satu sama lain, sehingga dari tiga dimensi internal dan lima dimensi eksternal akan diperoleh lima belas kombinasi yaitu identitas fisik, identitas moral-etika, identitas pribadi, identitas keluarga, identitas sosial, tingkah laku fisik, tingkah laku moral-etika, tingkah laku pribadi, tingkah laku keluarga, tingkah laku sosial, penerimaan fisik, penerimaan moral-etika, penerimaan pribadi, penerimaan keluarga, dan penerimaan social (Agustiani, 2009: 165).

\section{Masa Remaja Akhir}

Menurut Mappiare masa remaja berlangsung antara umur 12-21 tahun bagi wanita, dan 13-22 tahun bagi pria. Rentang usia remaja ini dapat dibagi menjadi dua bagian, yaitu usia 12/13 tahun sampai dengan 17/18 tahun adalah remaja awal, dan usia 17/18 tahun sampai dengan 21/22 tahun adalah remaja akhir. Dari pembagian Mappiare tersebut, dapat disimpulkan bahwa "Masa remaja akhir" ialah masa ketika seseorang individu berada pada usia 17/18 tahun sampai dengan 21/22 tahun. Dimana saat usia ini rata-rata setiap remaja memasuki sekolah menengah tingkat atas. Masa remaja akhir biasanya orang tua menganggapnya hampir dewasa dan berada diambang perbatasan untuk memasuki dunia kerja orang dewasa (Ali \& Asroni, 2004: 98).

Masa ini merupakan masa konsolidasi menuju periode dewasa dan ditandai dengan pencapain lima hal, yaitu (1) Minat menunjukkan kematangan terhadap fungsi-fungsi intelek, (2) Ego lebih mengarah pada mencari kesempatan untuk bersatu dengan orang lain dalam mencari pengalaman baru, (3) Terbentuk identitas seksual yang permanen atau tidak akan berubah lagi, (4) Egosentrisme (terlalu memusatkan perhatian pada diri sendiri) diganti dengan keseimbangan antara kepentingan diri sendiri dengan orang lain, (5) Tumbuh pembatas yang memisahkan diri pribadinya (Private Self) dengan masyarakat umum (Sarwono, 2012: 230). 
Dalam konteks psikologi perkembangan, pembentukan identitas merupakan tugas utama dalam perkembangan kepribadian yang diharapkan tercapai pada akhir masa remaja. Meskipun tugas pembentukan identitas ini telah mempunyai akar-akarnya pada masa anak-anak, namun masa remaja ia menerima dimensi-dimensi baru karena berhadapan dengan perubahanperubahan fisik, kognitif, dan relasional. Selama masa remaja ini, kesadaran akan identitas menjadi kuat, karena itu ia berusaha mencari identitas dan mendefinisikan kembali "siapakah" ia saat ini dan akan menjadi "siapakah" atau menjadi “apakah" ia pada masa yang akan datang (Desmita, 2006: 132).

Remaja adalah masa transisi dari periode anak-anak ke dewasa, dimana secara psikologis kedewasaan tentunya bukan hanya tercapainya usia tertentu seperti misalnya dalam ilmu hukum, secara psikologis kedewasaan ialah keadaan dimana sudah ada ciri-ciri psikologis tertentu pada seseorang. Terdapat pendapat yang mengatakan bahwa faktor perkembangan remaja akhir sangat tergantung dengan pembentukan konsep diri yang dia pahami, yaitu:

a. Pemahaman diri

Pemahaman diri adalah representasi kognitif remaja mengenai diri, substansi dan isi dari konsep konsep diri remaja.Dalam satu arti, pemahaman diri dari seorang remaja didasarkan sebagai peran dan jenis keanggotaan yang mereka ikuti, ini semua berperan dalam mendefinisikan dirinya (Santrock, 2007: 304).

\section{b. Konsep diri}

Konsep diri (self-concep) merujuk pada evaluasi yang menyangkut bidangbidang tertentu dari diri.Remaja melakukan evaluasi diri dalam berbagai bidangakademik, atletik, penampilan fisik dan sebagainya. Pembentukan konsep diri meliputi berbagai hal sebagai berikut: 1) Vocational/ carer identity, yaitu karir atau pekerjaan yang diinginkanseseorang untuk menjalankan. 2) Political identity, yaitu arah sikap politik seseorang. 3) Religious identity, yaitu keyakinan spiritual seseorang. 4) Relationship identity, yaitu terkait yang dengan status sesorang. 6) Achievement, yaitu motivasi seseorang untuk berprestasi. 7) Sexual 
identity, yaitu menyangkut orientasi seksual seseorang (Yusuf \& Sugandhi, 2014: 154).

Menurut Kuhlen bahwa ketika sudah memasuki masa remaja akhir, mulai tampak kecenderungan mereka untuk memilih karir tertentu meskipun dalam pemilihan karir tersebut masih mengalami kesulitan.Meskipun sebenarnya perkembangan karier remaja masih berada pada taraf pencarian karier.Untuk itu remaja perlu diberikan wawasan karier disertai dengan keunggulan dan kelemahan masing-masing jenis karier tersebut (Yusuf \& Sugandhi, 2014: 155).

\section{Kematangan Karir}

Karir merupakan sikap, aktivitas atau perilaku yang diasosiasikan dengan peran pekerjaan sepanajng kehidupan seseorang. Decenzo dan Robbins berpendapat bahwa karir adalah sebuah bentuk hubungan antara pekerjaan dengan pengalaman yang akan dicapai individu sepanjang kehidupannya. Sedangkan kematangan karir (career maturity) adalah kesiapan dan kapasitas individu dalam menangani tugas-tugas perkembangan terkait dengan keputusan karir (Rachmawati, 2013).

Menurut Crites kematangan karir adalah kesesuaian antara perilaku karir individu yang nyata sengan perilaku karir yang diharapkan pada usia tertentu di setiap tahap. Kesesuaian perilaku individu terhadap rangsangan dari lingkungan yang berkaitan dengan karir yaitu rangkain sikap dan kompetensi individu yang berkaitan dengan tingkat pendidikan, pengalaman dan aktivitas kerja selama rentang waktu kehidupan seseorang dengan rangkaian aktivitas pendidikan dan kerja yang terus kerkelanjutan, dengan demikian karir seorang individu melibatkan rangkaian pilihan dari berbagai macam kesempatan yang diharapkan dapat sesuai pada usia-usia tertentu yangnberkaitan dengan proses tahap perkembangan karir (Rachmawati, 2013).

Menurut Lavinson, Ohler, Caswell dan Kiewra dalam Yunia Eka Rachmawati (2013) mendefinisikan kematangan karir sebagai kemampuan individu dalam membuat suatu pilihan karir yang realistic dan stabil dengan menyadari akan apa yang dibutuhkan dalam membuat pilihan karir. Kematangan karir menurut 
Savickas adalah kesiapan individu dalam mebuat informasi, keputusan karir sesuai dengan usaha menyelesaikan tugas-tugas perkembangan terkait dengan karir.

Berdasarkan berbagai penjelasan dari beberapa tokoh di atas maka dapat menarik kesimpulan bahwa kematangan karir adalah suatu konsep kemampuan dan kapasitas individu untuk membuat suatu pilihan karir yang stabil dan realistis, serta menyelesaikan tugas-tugas perkembangan terkait dengan karir dengan menyadari hal-hal yang dibutuhkan dalam membuat suatu keputusan tentang karir.

Mengumpulkan dan memproses informasi karir tentang diri dan lingkungannya (terkait eksplorasi dan pengambilan keputusan karir) sebagai hal penting dalam proses pengembangan karir dan penyusunan konstruksi karir terutama bagi siswa yang tengah mengalami transisi menuju persiapan dunia karir yang sesungguhnya (Nota \& Rossier, 2015: 89-102). Keseluruhan proses pengumpulan informasi karir menurut siswa menggunakan kemampuan kognisi atau proses berpikir, salah satunya dengan bantuan tes minat jabatan yang nantinya hasil tes tersebut dapat memberikan banyak informasi terkait dengan minat dan bakat yang dimiliki siswa (Wahyuningsih \& Alhusin, 2019).

Dalam membantu siswa memahami hasil tes minat jabatan maka diperlukan adanya proses bimbingan dari guru BK untuk memberikan kejelasan dan informasi tindak lanjut dari hasil tes tersebut. Bimbingan diselenggarakan untuk membantu mengoptimalkan perkembangan siswa, salah satunya pengambilan keputusan karir. Kemampuan pengambilan keputusan karir siswa dapat diupayakan melalui program bimbingan karir. Bimbingan karir adalah suatu proses bantuan, layanan dan pendekatan terhadap siswa, agar siwa yang bersangkutan dapat mengenal dirinya, memahami dirinya dan mengenal dunia kerja, merencanakan masa depannya, dengan bentuk kehidupan yang diharapkannya, untuk menentukan pilihannya, dan mengambil suatu keputusan bahwa keputusan adalah yang paling tepat sesuai dengan keadaan dirinya 
dihubungkan dengan persyaratan-persyaratan dan tuntutan pekerjaan dan karir yang dipilihnya (Gani, 1996).

Pelaksanaan layanan karir dapat dilakukan secara kelompok, dengan menggunakan kelompok-kelompok kecil memungkinkan bagi siswa untuk dapat saling tukar pendapat. Menurut Sukardi dalam Diana Dewi dan Syahri Alhusin (2019) layanan bimbingan kelompok adalah layanan yang memungkinkan sejumlah peserta didik secara bersama-sama memperoleh bahan dari nara sumber tertentu (guru BK atau konselor) yang berguna untuk menunjang diskusi kelompok serta untuk pertimbangan dalam pengambilan keputusan. Menurut Prayitno dalam Diana Dewi dan Syahri Alhusin (2019) bahwa bimbingan kelompok adalah kegiatan yang dilakukan oleh sekelompok orang dengan megikut sertakan seluruh anggotanya untuk saling berinteraksi, bebas mengeluarkan pendapat,menanggapi, memberi saran, dan lain sebagainya. Apa yang dibicarakan itu semuanya bermanfaat untuk diri peserta dan peserta lainnya .

\section{Hasil}

Adapun hasil temuan yang peneliti temukan terkait konsep diri pada masa remaja akhir dalam kematangan karir, maka peneliti simpulkan ke dalam bebera point berikut ini:

a. Konsep diri merupakan gambaran yang dimiliki seseorang tentang dirinya, yang dibentuk melalui pengalaman-pengalaman yang diperoleh dari interaksi dengan lingkungan. Masa remaja akhir ialah masa ketika seseorang individu berada pada usia 17/18 tahun sampai dengan 21/22 tahun dan ketika sudah memasuki masa remaja akhir, mulai tampak kecenderungan mereka untuk memilih karir tertentu meskipun dalam pemilihan karir tersebut masih mengalami kesulitan. Sedangkan konsep diri pada masa remaja akhir merupakan merupakan masa menuju dunia pekerjaan atau karir yang sebenarnya.

b. Kematangan karir adalah suatu konsep kemampuan dan kapasitas individu untuk membuat suatu pilihan karir yang stabil dan realistic, serta 
menyelesaikan tugas-tugas perkembangan terkait dengan karir dengan menyadari hal-hal yang dibutuhkan dalam membuat suatu keputusan karir. Oleh karena itu, Kematangan karir pada masa remaja akhir dapat dimaksimalkan jika konsep diri pada seorang remaja akhir terpenuhi berdasarkan terpenuhinya faktor internal dan factor eksternal pada diri seorang remaja akhir.

\section{Simpulan}

Adapun simpulan dari penulisan artikel ini adalahkamatangan karir dapat diatasi jika seseorang pada masa remaja akhir dapat memaksimalkan konsep diri pada dirinya termasuk faktor internal dan eksternal didalamnya. Faktor internal yang dapat mempengaruhi konsep diri yakni: 1) diri identitas (identity self), 2) diri pelaku (behavioral self), dan 3) diri penerimaan atau penilaan (judging self). Sedangkan faktor eksternal yang dapat mempengaruhi konsep diri yakni: 1) diri fisik (physical self), 2) diri etika-normal (moral-ethical self), 3) diri pribadi (personal self), 4) diri keluarga (family self), dan 5) diri sosial (social self). Konsep diri perlu ada pada masa remaja akhir karena dengan keyakinan bahwa semua pencapaian ditentukan oleh usaha, keterampilan dan kemampuan, maka anak pada masa remaja akhir akan berusaha meningkatkan kemampuan dan keterampilan yang menjadi persyaratan karir. 


\section{DAFTAR PUSTAKA}

Agustiani, H. (2009). Psikologi Perkembangan (Pendekatan Ekologi Kaitannya dengan Konsep Diri dan Penyesuaian Diri pada Remaja. Refika Aditama.

Ali, M., \& Asroni, M. (2004). Psikologi Remaja (Perkembangan Peserta Didik). Bumi Aksara.

Bastomi, H. (2019). Konseling Cyber: Sebuah Model Konseling Pada Konteks Masyarakat Berbasis Online. Konseling Edukasi: Journal of Guidance and Counselling, 3, No. 1.

Desmita. (2006). Psikologi Perkembangan. Rosdakarya.

Dewi, Y. P., \& Mugiarso, H. (2020). Hubungan Antara Konsep Diri dengan Efikasi Diri dalam Memecahkan Masalah melalui Konseling Individu di SMK Hidayah Semarang. Konseling Edukasi: Journal of Guidance and Counseling, 4 (2).

Ghufron, N., \& Risnawita, R. (2016). Teori-teori Psikologi. Ar-Ruzz Media.

Killing, B. N. (2015). Tinjauan Konsep Diri dan Dimensinya pada Anak Masa Kanak-kanak Akhir. Psikologi Pendidikan Dan Konseling, 1 (1).

Leksana. (2013). Pengembangan Modul Bimbingan Karir Berbasis Multimedia Interaktif untuk Meningkatkan Karir Siswa. Bimbingan Konseling, 2 (1).

Nota, L., \& Rossier, J. (2015). Handbook of life design: From practice to theory and from theory to practice. MA: Hogrefe University Press.

Pratama, S. B. D. (2014). Hubungan antara Konsep Diri dan Internal Locus of Control dengan Kematangan Karir Siswa SMA. Psikologi Indonesia, 3.

Rachmawati, Y. E. (2013). Hubungan antara Self Efficacy dengan Kematangan Karir pada Mahasiswa Tingkat Awal dan Tingkat Akhir di Universitas Surabaya. Calyptra: Ilmiah Mahasiswa Universitas Surabaya, 1 (1).

Rahman, A. A. (2014). Psikologi Sosial: Integrasi Pengetahuan Wahyu dan Pengetahuan Empirik. Raja Grafindo Persada.

Santrock, J. W. . (2007). Remaja Jilid 1. Penerbit Erlangga.

Sarwono, S. W. (2012). Psikologi Remaja. Raja Grafindo Persada.

Sugiyono. (2016). Metode Penelitian Kuantitatif, Kualitatif, dan R\& D. Alfabeta.

Sukmadinata, N. S. (2005). Metode Penelitian Pendidikan. Remaja Rosadakarya. 
Suwargarini, R. (2018). Gambaran Psikologi: Konsep Diri pada Anak Usia Sekolah Dasar di Wilayah Banjir Rob. Ilmu Keperawatan Dan Kebidanan, 5 (2).

Wahyuningsih, D. D., \& Alhusin, S. (2019). Upaya Meningkatkan Kemampuan Pengambilan Keputusan Karir Melalui Layanan Bimbingan Kelompok. Konseling Edukasi: Journal of Guidance and Counseling, 3 (2).

Yusuf, S., \& Sugandhi, N. M. (2014). Perkembangan Peserta Didik. Raja Grafindo Persada.

Zed, M. (2004). Metode Penelitian Kepustakaan. Yayasan Obor Indonesia. 